\title{
Palkokasvien, herneen, härkäpavun, sini- ja valkolupiinin sekä soijan kemiallinen laatu Suomen oloissa viljeltynä
}

\author{
Marketta Saastamoinen ${ }^{1)}$ ja Merja Eurola ${ }^{2)}$ \\ ${ }^{1}$ Satafood Kehittämisyhdistys ry, Viialankatu 25, 32700 Huittinen, marketta.saastamoinen@ satafood.net \\ ${ }^{2)}$ MTT, Kasvintuotannon tutkimus, 31600 Jokioinen, merja.eurola@ mtt.fi
}

\section{Tiivistelmä}

Satafood Kehittämisyhdistys ry:llä on Manner-Suomen maaseudun kehittämisrahoituksella oleva Alituotantokasvien tuotannon kehittäminen -hanke, jossa kehitetään mm palkokasvien viljelyä. Hankkeessa on toteutettu uusien palkokasvien $\mathrm{mm}$. sini-, valkolupiinin ja soijan koeviljelyä viljelijöiden pelloilla. Palkokasvit ovat typpiomavaraisia proteiinirikkaita kasveja, joilla pystytään katkaisemaan viljanviljelykierto.

Viljelyksiltä on kerätty viljely- ja satotietoja sekä satonäytteitä. Näytteitä saatiin Karita, Hulda ja Stok herneestä, Kontu ja Fuego härkäpavusta, Haags Blaue ja Sonet sinilupiinista, Dieta valkolupiinista ja Elena soijapavusta. Herneestä ja härkäpavusta määritettiin proteiinipitoisuus. Sini- ja valkolupiinin sekä soijan näytteistä analysoitiin rehuanalyysi. Jokaisesta kasvilajista määritettiin aminohappoanalyysi ja kaikista vuoden 2010 näytteistä määritettiin fytiinihappopitoisuus.

Stok-herneessä oli matalampi proteiinipitoisuus $(214 \mathrm{~g} / \mathrm{kg})$ Karitaan $(234 \mathrm{~g} / \mathrm{kg})$ ja Huldaan $(223 \mathrm{ja} 239$ $\mathrm{g} / \mathrm{kg}$ ) verrattuna. Kontu härkäpavun proteiinipitoisuus oli jonkin verran korkeampi kuin Fuegon. Haags Blaue sinilupiinin proteiinipitoisuus oli vuonna 2010 keskimäärin $229 \mathrm{~g} / \mathrm{kg}$ ja vuonna $2011317 \mathrm{~g} / \mathrm{kg}$. Sinilupiini Sonetin proteiinipitoisuus oli $308 \mathrm{~g} / \mathrm{kg}$. Sinilupiininäytteiden rasvapitoisuus vaihteli $30-49 \mathrm{~g} / \mathrm{kg}$. Soijassa ja valkolupiinissa oli korkeimmat proteiini- ja rasvapitoisuudet. Elena soijapavun proteiinipitoisuus oli $379 \mathrm{~g} / \mathrm{kg}$ ja Dieta valkolupiinin $382 \mathrm{~g} / \mathrm{kg}$. Elenan rasvapitoisuus oli $100 \mathrm{~g} / \mathrm{kg}$ ja Dieta valkolupiinin 101 $\mathrm{g} / \mathrm{kg}$. Sinilupiinin kuitupitoisuus oli korkeampi kuin valkolupiinin ja soijan. Soijapapu ja valkolupiini olivat rehuanalyysituloksiltaan lähes samanarvoiset.

Herne, härkäpapu, sini- ja valkolupiini sekä soija poikkesivat toisistaan aminohappokoostumuksen suhteen. Herneen $(7,8 \mathrm{~g} / 100 \mathrm{~g})$ ja härkäpavun $(7,1 \mathrm{~g} / 100 \mathrm{~g})$ proteiinissa oli enemmän lysiiniä kuin soijan $(6,8 \mathrm{~g} / 100 \mathrm{~g})$ tai sini- $(5,8 \mathrm{~g} / 100 \mathrm{~g})$ ja valkolupiinin $(5.0 \mathrm{~g} / 100 \mathrm{~g})$ proteiinissa. Korkein rikkipitoisten aminohappojen metioniinin ja kystiinin määrä oli soijassa (3,3 g/100 g). Myös sinilupiinissa rikkipitoisten aminohappojen määrä oli melko korkea $(2,9 \mathrm{~g} / 100 \mathrm{~g})$ proteiinia.

Tutkittujen palkoviljojen fytiinihappopitoisuudet olivat erilaiset. Rehussa fytiinihappo alentaa 1mahaisten eläinten kasvua. Matalin fytiinihappopitoisuus oli valkolupiinissa $(6,2 \mathrm{mg} / \mathrm{g} \mathrm{ka})$ ja korkein soijapapu Elenassa $(22,6 \mathrm{mg} / \mathrm{g} \mathrm{ka})$. Fuego härkäpavun fytiinihappopitoisuus $(11,7 \mathrm{mg} / \mathrm{g} \mathrm{ka})$ oli alempi kuin Kontu härkäpavun pitoisuus (16,5 mg/g ka). Haags Blaue sinilupiinin fytiinihappopitoisuus $(13,6 \mathrm{mg} / \mathrm{g} \mathrm{ka})$ oli matalampi kuin Kontu härkäpavun, mutta kuitenkin korkeampi kuin hernelajikkeiden vastaavat arvot. Hernelajikkeilla Karitalla $(9,6 \mathrm{mg} / \mathrm{g} \mathrm{ka})$ ja Huldalla $(11,1 \mathrm{mg} / \mathrm{g}$ ka $)$ oli toiseksi matalimmat fytiinihappopitoisuudet valkolupiinin jälkeen.

Vähän viljellyistä palkokasveista sini- ja valkolupiini ovat mielenkiintoiset valkuaiskasvit Suomen peltoviljelyyn.

Avainsanat: herne, härkäpapu, lupiini, soija, valkuainen, rasva, aminohapot, fytiinihappo 


\section{Johdanto}

Satafood Kehittämisyhdistys ry:1lä on 'Alituotantokasvien tuotannon kehittäminen' hanke EU:n MannerSuomen maaseudun kehittämisohjelmasta, minkä puitteissa on kehitetty niiden peltokasvien viljelyä, joista Suomessa on alituotantotilanne. Hankkeessa ovat mukana mm palkokasvit. Hankkeessa on pyritty lisäämään palkokasvien herneen (Pisum sativum L.)ja härkäpavun (Vicia faba L.) viljelyä ja löytämään viljelyyn vähemmän viljeltyjä uusia palkokasveja. Hankkeessa on ollut viljelyssä mm sinilupiinia (Lupinus angustifolius L.), valkolupiinia (Lupinus albus L.), ja soijapapua (Glycine max (L.) Merril). Palkokasvit ovat typpiomavaraisia ja tulevat toimeen pienellä lannoituksella, joka on nykyään peltoviljelyn suurin taloudellinen kustannus. Palkokasvien proteiinipitoisuus on yleensä korkea ja aminohappokoostumus hyvä. Palkokasvien välillä on kuitenkin eroja laadussa, proteiini- ja rasvapitoisuudessa, raakakuidun ja tuhkan määrässä ja proteiinin aminohappokoostumuksessa sekä haitallisten aineiden määrissä. Hankkeessa on kerätty viljelijöiden satonäytteitä ja viljelytietoja ja analysoitu satojen laatua.

\section{Aineisto ja menetelmät}

Viljelijöiltä on kerätty viljelytietoja ja satonäytteitä. Vuosi 2010 oli hyvin lämmin ja edullinen kasvuolosuhteiltaan, minkä vuoksi vaateliaammistakin kasvilajeista saatiin satoa Suomen olosuhteissa. Vuosi 2011 oli runsassateinen, minkä vuoksi vaateliaammat palkokasvit soija ja valkolupiini eivät ehtineet kunnolla tuleentua. Näytteitä saatiin seuraavista palkokasveista: Karita, Hulda ja Stok herneestä, Kontu ja Fuegohärkäpavusta, Haags Blaue ja Sonet-sinilupiinista, Dieta-valkolupiinista ja Elena-soijasta. Kaikista näytteistä on määritetty valkuais- eli proteiinipitoisuus ja kosteus. Lupiini- ja soijanäytteistä määritettiin rehuanalyysi: kosteus-, raakaproteiini-, raakarasva-, raakakuitu- ja tuhkapitoisuus sekä typettömien uuteaineiden määrä. Määritykset tehtiin Viljavuuspalvelu Oy:ssä. Kustakin kasvilajista määritettiin myös proteiinin aminohappoanalyysi vuoden 2010 sadosta. Aminohappoanalyysit suoritettiin Eurofins Scientific Oy:ssä. Kaikista vuoden 2010 näytteistä määritettiin fytiinihappopitoisuus. Fytiinihappopitoisuudet määritettiin MTT:n kemian laboratoriossa Plaamin ja Kumpulaisen (1991) esittämällä menetelmällä.

\section{Tulokset ja tulosten tarkastelu}

Herne- ja härkäpapulajikkeiden valkuaispitoisuus vaihteli jonkin verran. Karita-herneen proteiinipitoisuus oli keskimäärin 234 g/kg kuiva-ainetta ja Hulda-herneen keskimäärin 223 g/kg vuonna 2010 ja 239 g/kg vuonna 2011 (Taulukko 1). Stok-herneen proteiinipitoisuus oli matalampi eli $214 \mathrm{~g} / \mathrm{kg}$ vuonna 2011. Kontuhärkäpavun proteiinipitoisuus oli keskimäärin 300 g/kg ja Fuego-härkäpavun 298 g/kg kuiva-ainetta vuonna 2010. Vuoden 2011 sadossa härkäpavun proteiinipitoisuudet olivat vähän korkeammat. Fuego-härkäpavun proteiinipitoisuustaso on ehkä hiukan Kontua matalampi. Herne- ja härkäpapulajikkeiden proteiinipitoisuudet olivat hyvin tavanomaiset.

Sini- ja valkolupiinilajikkeiden sekä soijanäytteen rehuanalyysitulokset on esitetty Taulukossa 1. Sinilupiini Haags Blauen proteiinipitoisuus oli keskimäärin $229 \mathrm{~g} / \mathrm{kg}$ vuonna 2010, mikä oli matalampi arvo kuin kirjallisuudessa yleensä sinilupiinille annetaan (Mohammed ja Rayas-Duarte 1995). Vuoden 2011 näytteessä Haags Blaue sinilupiinin proteiinipitoisuus oli kuitenkin korkea $317 \mathrm{~g} / \mathrm{kg}$. Sonet sinilupiinin proteiinipitoisuus oli korkea $308 \mathrm{~g} / \mathrm{kg}$ kuiva-ainetta vuonna 2010. Valkolupiini Dieatan $382 \mathrm{~g} / \mathrm{kg}: \mathrm{n}$ proteiinipitoisuusarvo oli yhtä hyvä kuin Elena soijapavun proteiinipitoisuus $379 \mathrm{~g} / \mathrm{kg}$. Sinilupiini Haags Blauen rasvapitoisuus oli korkeampi, $49 \mathrm{~g} / \mathrm{kg}$, kuin Sonet-sinilupiinin rasvapitoisuus $41 \mathrm{~g} / \mathrm{kg}$ kuiva-ainetta vuonna 2010. Vuonna 2011 Haags Blaue sinilupiinin rasvapitoisuus oli matalampi $30 \mathrm{~g} / \mathrm{kg}$. Valkolupiini Dietan rasvapitoisuus, $101 \mathrm{~g} / \mathrm{kg}$, oli yhtä hyvä kuin Elena-soijapavun rasvapitoisuus $100 \mathrm{~g} / \mathrm{kg}$. Sinilupiinilajikkeiden raakakuitupitoisuus oli korkeampi kuin valkolupiinin ja soijan. Tuhka- ja raakakuitupitoisuus olivat matalimmat valkolupiini Elenassa. Mohammed ja Rayas-Duarte (1995) ovat raportoineet valkolupiinille $38 \%$, sinilupiinille $34,8 \%$ ja soijalle $34 \%$ proteiinipitoisuuden. MartinezVillaluega ym. (2006) ovat raportoineet valkolupiinista matalampaa proteiinipitoisuutta edustavan Multolupa-lajikkeen $(30,6 \mathrm{~g} / 100 \mathrm{~g})$ ja korkeamman valkuaispitoisuuden Marta lajikkeen $(37,4 \mathrm{~g} / 100 \mathrm{~g})$. 
Rehuanalyysin perusteella Dieta-valkolupiini on yhtä hyvä laadultaan kuin soijapapu. Valkolupiini on Suomessa kuitenkin aikaisempi kuin soija, vaikka sekään ei ehdi tuleentua joka vuosi.

Taulukko 1. Herne- ja härkäpapulajikkeiden proteiinipitoisuus ja sini- ja valkolupiini- ja soijalajikkeiden rehuanalyysi sekä lajikkeiden fytiinihappopitoisuudet keskiarvoina viljelijöiden näytteissä vuoden 2010 ja 2011 sadossa

\begin{tabular}{|c|c|c|c|c|c|c|c|c|c|}
\hline Kasvilaji & Lajike & Vuosi & $\begin{array}{c}\text { Näytteitä } \\
\mathrm{n}\end{array}$ & $\begin{array}{c}\text { Proteiini- } \\
\text { pitoisuus } \\
\text { g/kg ka. }\end{array}$ & $\begin{array}{c}\text { Rasva- } \\
\text { pitoisuus } \\
\text { g/kg ka. }\end{array}$ & $\begin{array}{c}\text { Raaka- } \\
\text { kuitu- } \\
\text { pitoisuus } \\
\text { g/kg ka. }\end{array}$ & $\begin{array}{c}\text { Tuhka- } \\
\text { pitoisuus } \\
\text { g/kg ka. }\end{array}$ & $\begin{array}{c}\text { Typettö- } \\
\text { mät } \\
\text { uute- } \\
\text { aineet } \\
\text { g/kg ka. }\end{array}$ & $\begin{array}{c}\text { Fytiini- } \\
\text { happo- } \\
\text { pitoisuus } \\
\text { mg/g ka. }\end{array}$ \\
\hline Herne & Hulda & 2010 & 1 & 223 & & & & & 11,1 \\
\hline & & 2011 & 1 & 239 & & & & & \\
\hline & Karita & 2010 & 6 & 234 & & & & & 9,6 \\
\hline & Stok & 2011 & 2 & 214 & & & & & \\
\hline Härkäpapu & Fuego & 2010 & 1 & 298 & & & & & 11,7 \\
\hline & & 2011 & 1 & 305 & & & & & \\
\hline & Kontu & 2010 & 5 & 300 & & & & & 16,5 \\
\hline & & 2011 & 5 & 324 & & & & & \\
\hline Sinilupiini & Haags Blaue & 2010 & 4 & 229 & 49 & 178 & 47 & 498 & 13,6 \\
\hline & & 2011 & 1 & 317 & 30 & 239 & 48 & 366 & \\
\hline & Sonet & 2010 & 1 & 308 & 41 & 157 & 43 & 451 & \\
\hline Valkolupiini & Dieta & 2010 & 1 & 382 & 101 & 141 & 31 & 345 & 6,2 \\
\hline Soijapapu & Elena & 2010 & 1 & 279 & 100 & 149 & 44 & 328 & 22,6 \\
\hline
\end{tabular}

Proteiinin aminohappokoostumus oli erilainen eri palkokasveilla. Lysiini on yleensä viljojen proteiinin arvoa rajoittava aminohappo. Lysiinin määrä palkokasveissa on yleensä korkea, mutta niissä on yleensä liian vähän rikkipitoisia aminohappoja metioniinia ja kystiiniä. Soijassa oli eniten sekä lysiiniä että rikkipitoisia aminohappoja metioniinia ja kystiiniä yhteensä kuiva-ainekiloa kohden laskettuna (Kuva 1). Karita-herneen, Kontu-härkäpavun ja Dieta-valkolupiinin lysiinin määrä $\mathrm{g} / \mathrm{kg}$ kuiva-ainetta oli suunnilleen sama. Valkolupiinissa ja myös sinilupiini Haags Blauessa on enemmän rikkipitoisia aminohappoja kuin Karitaherneessä ja Kontu-härkäpavussa. Herneen ja härkäpavun proteiinissa on enemmän lysiiniä g/kg proteiinia kuin sini- ja valkolupiinissa ja soijassa (Kuva 2). Rikkipitoisten aminohappojen metioniinin ja kystiinin määrä on sen sijaan herneen ja härkäpavun proteiinissa pienempi kuin sini- ja valkolupiinin ja soijan proteiinissa (Kuva 2). Sinilupiini Haags Blauessa on enemmän sekä lysiiniä että rikkipitoisia aminohappoja 100 grammassa proteiinia kuin valkolupiinissa. Valkolupiinissa on paljon proteiinia, mutta se on vähän heikkolaatuisempaa kuin sinilupiini Haags Blauen proteiini. Sekä herneen että härkäpavun ja sini- ja valkolupiinin lysiinipitoisuudet $(\mathrm{g} / 100 \mathrm{~g}$ proteiinia) olivat jonkin verran korkeammat kuin kirjallisuudessa esitetyt arvot (El-Adawy ym. 2001, Mariscal-Landin ym. 2002). Eri kasvilajien väliset erot olivat kuitenkin samanlaiset kuin aikaisemmissa tutkimuksissa on esitetty.

Kaikista näytteistä määritettiin myös fytiinihappopitoisuus rehuarvoa rajoittavana haitallisena aineena (Taulukko 1). Fytiinihappo, myoinnositolin heksafosforihappo, joka sisältää 6 fosforiatomia jokaisessa molekyylissä. Fytiinihappoa on sekä 1- että 2-sirkkaisten kasvien siemenissä. Se on siemenissä suuri fosforivarasto. Fytiinihappo sitoo kivennäisaineita, kalsiumia $(\mathrm{Ca})$, magnesiumia $(\mathrm{Mg})$, rautaa $(\mathrm{Fe})$ ja sinkkiä (Zn) aiheuttaen näiden kivennäisaineiden puutetta ja esim. anemiaa ihmisellä ja 1-mahaisilla eläimillä. Fytiinihapon on todettu pienentävän sekä herneen että härkäpavun proteiinin sulavuutta (Carnovale ym. 1988). Märehtijöiden pötsin mikrobeilla on fytaasientsyymi, joka pystyy hajottamaan fytiinihapon. Näille eläimille fytiinihappo on fosforin lähde. Fytiinihapon haitallisia vaikutuksia voidaan estää 1-mahaisilla eläimillä rehuissa käytettävillä fytaasientsyymeillä (Urbano ym. 2007). Fytiinihappo on siementen suurin fosforivaranto. Monien kasvien esim. palkokasvien siemenet sisältävät yleensä paljon fytiinihappoa.

Palkokasvien lajikkeiden välillä oli suuria eroja fytiinihappopitoisuuksissa (Taulukko 1). Korkein fytiinihappopitoisuus oli Elena-soijassa $22,6 \mathrm{mg} / \mathrm{g}$ kuiva-ainetta ja vastaavasti pienin pitoisuus oli Dietavalkolupiinissa $6,2 \mathrm{mg} / \mathrm{g}$ kuiva-ainetta. Myös aikaisemmissa tutkimuksissa on havaittu valkolupiinissa huomattavasti matalampi fytiinihappopitoisuus $(0,03 \%)$ soijapapuun $(1,56 \%)$ verrattuna (Mohammed ja 
Ryas-Duarte 1995). Martinez-Villaluenga ym.(2006) ovat raportoineet $0,25 \mathrm{~g} / 100 \mathrm{~g}$ ja $0,44 \mathrm{~g} / 100 \mathrm{~g}$ olevia pitoisuuksia valkolupiinille. Valkolupiinin proteiinikonsentraateissa on löytynyt $0,21 \%$ ja $0,33 \%$ fytiinihappoa (El-Adawy ym. 2001). Elena-soijan jälkeen korkein fytiinihappopitoisuus oli Kontuhärkäpavussa, $16,5 \mathrm{mg} / \mathrm{g}$. Alfonso ym. (2000) ovat raportoineet kuitenkin vielä korkeamman fytiinihappopitoisuuden $(21,7 \mathrm{~g} / \mathrm{kg})$ härkäpavulle. Fuego-härkäpavun fytiinihappopitoisuus oli selvästi matalampi $11,7 \mathrm{mg} / \mathrm{g}$ kuin Kontu-härkäpavun ollen suunnilleen samalla tasolla kuin Hulda-herneen fytiinihappopitoisuus, $11,1 \mathrm{mg} / \mathrm{g}$. Sinilupiini Haags Blauen fytiinihappopitoisuus, $13,6 \mathrm{mg} / \mathrm{g}$, oli korkeampi kuin valkolupiinin pitoisuus.

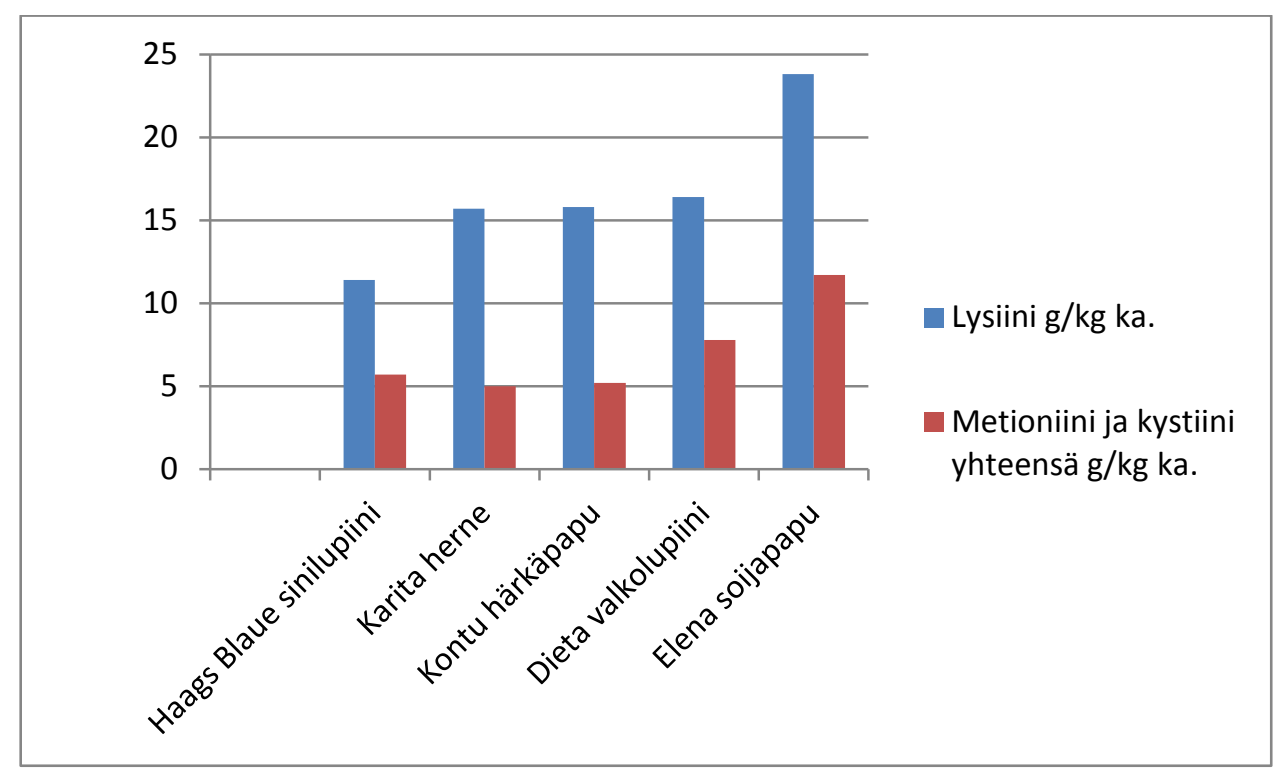

Kuva 1. Herneen, härkäpavun, sini- ja valkolupiinin sekä soijan proteiinin lysiinin ja metioniini + kystiinin määrät sadossa (g/kg kuiva-ainetta)

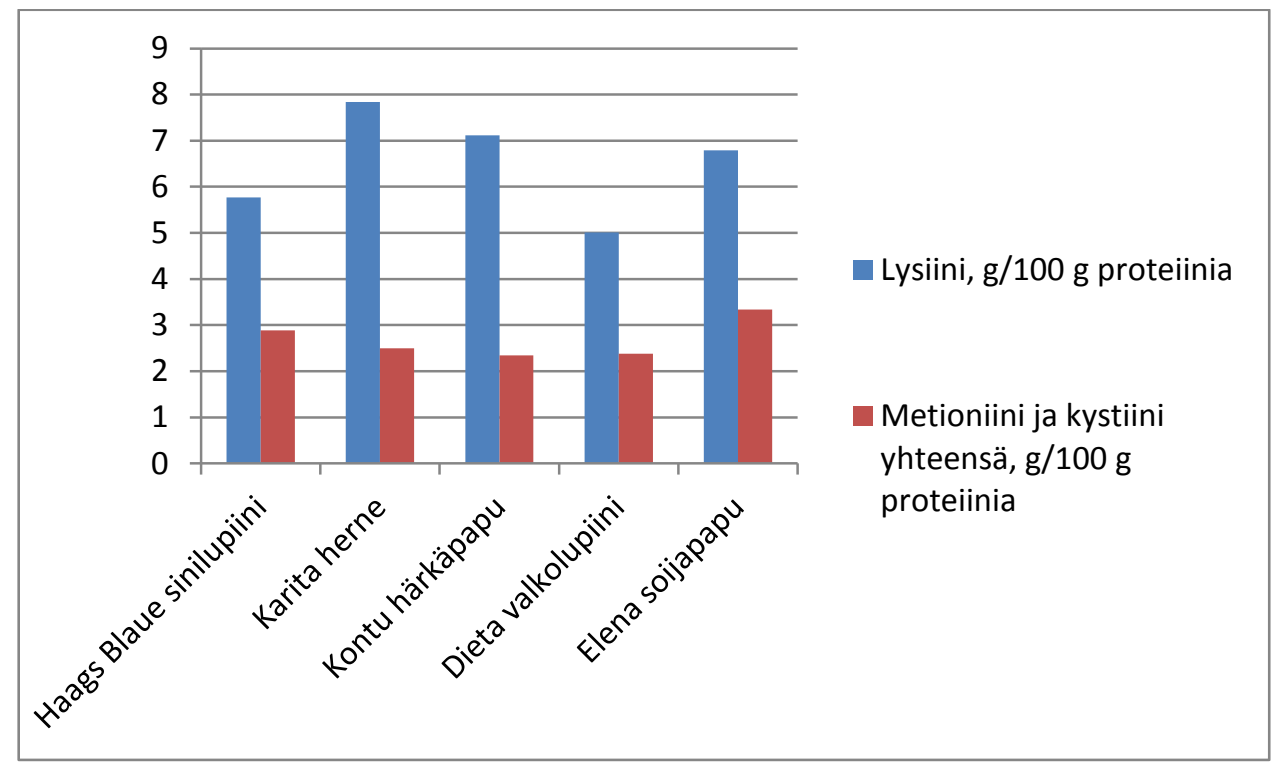

Kuva 2. Herneen, härkäpavun, sini- ja valkolupiinin sekä soijan proteiinin lysiinin ja metioniini + kystiinin pitoisuudet ( $\mathrm{g} / 100 \mathrm{~g}$ proteiinia) 
Sekä sini- että valkolupiini ovat mielenkiintoisia palkokasveja, joilla on tiettyjä etuja tähän saakka yleisesti viljeltyihin palkokasveihin herneeseen ja härkäpapuun verrattuna ja jotka mahdollistavat palkokasvivalikoiman laajentumisen Suomen peltoviljelyssä. Sini- ja valkolupiinin proteiinin määrä on korkea ja rikkipitoisten aminohappojen määrä satokilossa on korkeampi kuin herneessä ja härkäpavussa. Lisäksi valkolupiinin fytiinihappopitoisuuden määrä on hyvin matala, mikä mahdollistaisi valkolupiinin käytön kotovaraisena lähellä soijan laatua olevana rehuna. Myös sinilupiinin fytiinihappopitoisuus vaikuttaa matalammalta kuin härkäpavun.

\section{Kiitokset}

Esitämme parhaimmat kiitokset kaikille hankkeessa palkokasvinäytteitä ja lohkotietoja lähettäneille viljelijöille.

\section{Kirjallisuus}

Alfonso, R., Aguirre, A. \& Marzo, F. 2000. Effects of extrusion and traditional processing methods on antinutritients and in vitro digestibility of protein and starch in faba and kidney beans. Food Chemistry 68: 159-165.

Carnovale, E., Lugaro, E. \& Lombardi-Boccia, G. 1988. Phytic acid in faba bean and pea: Effect on protein availability. Cereal Chemistry 65: 114-117.

El-Adawy, T.A., Rahma, E.H., El-Bedawey, A.A. \& Gafar, A.F. 2001. Nutritional potential and functional properties of sweet lupin seed protein isolates. Food Chemistry 74: 455-462.

Plaami, S. \& Kumpulainen, J. 1991. Determination of phytic acid in cereals using ICP-AES to determine phosphorus. Journal of the Association of Official Analytical Chemists 74: 32-36.

Mariscal-Landin, G., Lebreton, Y. \& Seve, B. 2002. Apparent and standardized true ileal digestibility of protein and amino acids from faba bean, lupin, and pea, provided as whole seeds, dehulled and extruded in pig diets. Animal Feed Science and Technology 97: 183-198.

Martinez-Villaluenga, C., Frias, J. \& Vidal-Valverde, C. 2006. Functional lupin seeds (Lupinus albus L. and Lupinus luteus L.) after extraction of $\alpha$-glalactosides. Food Chemistry 98: 291-299.

Mohammed, A.A. \& Ryas-Dijarte, P. 1995. Composition of Lupinus albus. Cereal Chemistry 72: 643-647.

Urbano, G., Frejnagel, S., Porres, J.M., Aranda, P., Gomez-Villalva, E., Frias, J. \& Lopez-Jurado, M. 2007. Effect of phytic acid degradation by soaking and exogenous phytase on the bioavailability of magnesium and from Pisum sativum L. European Food Research and Technology 226: 105-111. 